\title{
KORIŠTENJE I STAVOVI NASTAVNIKA O IGRIFIKACIJI U OSNOVNIM I SREDNJIM ŠKOLAMA ${ }^{4}$
}

\section{SAŽETAK}

Tijekom posljednjih nekoliko godina koncept igrifikacije je, zbog svog utjecaja na motivaciju i angažman učenika, privukao veliku pažnju znanstvenika i učitelja. Ovaj obrazovni pristup, koji uključuje mehanike igara koje se primjenjuju u nastavnom radu, uglavnom je istražen u kontekstu visokog obrazovanja dok su istraživanja povezana s nižim razinama obrazovanja rijetka. U radu su prikazani rezultati anketnog istraživanja provedenog među 124 učitelja iz tri osnovne i dvije srednje škole u Hrvatskoj. Učitelji su ispitivani o korištenju igrifikacije u svom nastavnom radu kao i o stavovima prema igrifikaciji općenito. Rezultati istraživanja daju uvid u profile učitelja koji koriste ili ne koriste igrifikaciju u realizaciji nastave te identificiraju mehanike i aplikacije koje se koriste. Prikazana su mišljenja učitelja o tome koji su razlozi za (ne)uvođenje igrifikacije u nastavu. Prema rezultatima istraživanja moguće je zaključiti kako je manje od polovine ispitanika upoznato s konceptom igrifikacije, te ga primjenjuje u svom radu. Rezultati istraživanja pokazuju da se većina učitelja upoznala s konceptom igrifikacije na osobnu inicijativu. Bodovi, zadaci i priče su mehanike igrifikacije koje ispitanici najčešće primjenjuju u svom radu. Predmeti u kojima ispitanici najčešće koriste igrifikaciju su matematika, hrvatski jezik te strani jezici. Također, ispitanici se u visokom postotku slažu s učincima i utjecajima igrifikacije na motivaciju te angažman učenika, koji predstavljaju prednosti igrifikacije. Kao razloge za nekorištenje igrifikacije ispitanici navode nedostatak vremena i formalne razloge, dok kao razloge za korištenje igrifikacije navode povećanje motivacije i angažmana učenika, što je zapravo i cilj koncepta igrifikacije.

Ključne riječi: igrifikacija, učitelji, osnovna škola, srednja škola, anketa

\section{UVOD}

Ubrzani razvoj tehnologije na različite načine utjecao je na društvo u cjelini. Tehnologija je postala sastavni dio svakodnevice gotovo svakog čovjeka. Kao sveprisutan element često olakšava dio aktivnosti, ali i pruža zabavne i razonodne sadržaje kroz društvene mreže, različite medije te

1 Dr. sc., docent, Fakultet organizacije i informatike, Sveučilište u Zagrebu, Pavlinska 2, 42000 Varaždin, Hrvatska. E-mail: dijana.plantak@foi.hr

2 Mag. edu. inf., E-mail: majaskara1990@gmail.com

3 Dr. sc., docent, Fakultet organizacije i informatike, Sveučilište u Zagrebu, Pavlinska 2, 42000 Varaždin, Hrvatska. E-mail: goran.hajdin@foi.hr

4 Datum primitka rada: 15. 1. 2018.; datum prihvaćanja rada: 1. 3. 2018. 
računalne igre. Industrija računalnih igara također ubrzano raste, što je rezultiralo time da se gotova svaka osoba susrela s nekim oblikom računalnih igara.

U kontekstu hrvatskog odgojno-obrazovnog sustava potrebna je aktualizacija i integracija novog kurikuluma koji će uvažiti potrebe učenika čije je prirodno okruženje informacijsko-komunikacijska tehnologija. Integracija tehnologije u odgojno-obrazovni rad u obliku njezinog klasičnog korištenja nije jedini oblik njezinog korištenja. Jedan od suvremenih oblika jest korištenje koncepta igrifikacije kojim se želi utjecati na povećanje interesa učenika, njihovu motivaciju te osnaženje komunikacije i dijeljenja (Medica Ružić, Dumančić, 2015).

Dosad je igrifikacija najviše istražena u kontekstu visokog obrazovanja (npr. de Byl, Hooper, 2013; Jensen, 2016; Laskowski, Borys, 2016; Ortiz et al., 2016), dok su istraživanja povezana s nižim razinama obrazovanja rijetka i recentna (npr. Isayama et al., 2016; Jagušt et al., 2017).

Kako bismo se upoznali s opsegom i stavovima o korištenju igrifikacije u osnovnim i srednjim školama u Hrvatskoj, provedeno je pokusno istraživanje čiji su rezultati prikazani u ovom radu. U nastavku rada objašnjen je pojam igrifikacije te pojmovi koji se često zamjenjuju za igrifikaciju. Zatim je dan pregled istraživanja drugih autora koji su istraživali temu igrifikacije u kontekstu obrazovanja. U četvrtom poglavlju opisana je metodologija istraživanja koje je predstavljeno u ovom radu, o korištenju i stavovima o igrifikaciji među učiteljima osnovnih i srednjih škola u Hrvatskoj. $U$ petom poglavlju prikazani su rezultati istraživanja. Na kraju rada diskutirani su rezultati provedene analize i dani zaključci, uz moguće nove smjerove istraživanja.

\section{2. ŠTO JE IGRIFIKACIJA?}

Da bi se moglo govoriti o igrifikaciji potrebno je definirati sam pojam, iako jedinstvena definicija ne postoji. Preciznu definiciju igrifikacije (engl. Gamification) dali su Deterding i suradnici (2011) u radu „From Game Design Elements to Gamefulness: Defining 'Gamification', koji je jedan od prvih i najčešće citiranih znanstvenih radova o igrifikaciji (Martí-Parreño i sur., 2016). Deterding i sur. (2011) definiraju igrifikaciju kao „korištenje elemenata dizajna igre u neigraćem kontekstu“ i navode njenu primjenu u različitim kontekstima: proizvodnji, poslovanju, financijama, zdravlju, obrazovanju itd., te opisuju temelje igrifikacije koji vuku korijene iz teorije i industrije računalnih igara, digitalnih medija i dizajna korisničkih sučelja.

Glavna ideja igrifikacije jedinstvena je svim kontekstima i definicijama, a definira se kao korištenje mehanika igara, estetike igara i njihovih strategija s ciljem motiviranja i aktiviranja ljudi; odnosno, integracija elemenata igara i strategija (pravila) igara u aktivnosti koje nisu igra. $U$ kontekstu obrazovanja igrifikacija se primjenjuje kako bi se unaprijedilo učenje $i$ rješavanje problema. Igrifikacija se integrira korištenjem mehanika kao što su bedževi, sakupljanje bodova, razine te razni oblici nagrada. Zbog toga što su te mehanike zapravo elementi igara, tj. preuzeti su iz igara i adaptirani za nezabavni kontekst, vjeruje se da učenici gledaju na odgojno-obrazovne ciljeve kao nešto dinamično, zabavno i proaktivno, a ne kao nešto nezanimljivo i obvezno (McGrath, Bayerlein, 2013; Kiryakova et al., 2014; Sandusky, 2017). 
Igrifikacija nije jedini koncept povezan s računalnim igrama koji se može integrirati u aktivnosti koje nisu primarno igra, pa ju je potrebno razlikovati od sličnih koncepata. Ovaj koncept najčešće se izjednačava s konceptom ozbiljnih igara (engl. Serious games) koji predstavlja primjenu kompletne računalne igre u određenu svrhu. Koncept igrifikacije često se izjednačava $s$ konceptom učenja temeljenog na igri (engl. Game-based learning) koji zapravo predstavlja nadopunu klasičnoj nastavi kroz primjenu tehnologije i igara u svrhu stjecanja znanja i vještina, a u tom slučaju najčešće se radi o edukativnim videoigrama (Martí-Parreño et al. 2016; Kiryakova et al., 2014; Jackson, 2016; Pivac, 2006; Franković, 2016; Edmonds, 2011).

Integracija igrifikacije u nastavu treba se zasnivati na poznavanju i uvažavanju principa na igrifikacije. Fui-Hoon Nah i suradnici (2013) u svom radu navode i opisuju pet osnovnih principa igrifikacije, a to su:

- Orijentiranost cilju govori o tome da svaka igrificirana aktivnost mora biti usmjerena cilju, koji se razlaže na manje ciljeve, razine i zadatke. Time se sistematizira ostvarivanje cilja, a sve aktivnosti moraju biti usmjerene njegovom izvršavanju.

- Uspjeh ili postignuće odnosi se na ostvarivanje uspjeha ili postignuća odnosno cilja, što rezultira osjećajem zadovoljstva te utječe na povećanje motiviranosti i angažmana učenika u budućim aktivnostima.

- Poticanje se zasniva na čestoj praksi igara koje imaju sustav nagrađivanja kao poticaja za sudionike za ostvareni rezultat. Najčešće se realizira sustavom povratne veze koje mogu biti pozitivne u pogledu (ne)materijalnih nagrada te negativne (znanja i vještine potrebne postizanje ciljeva, informacije što treba mijenjati).

- Natjecanje je karakteristično za klasične igre jer ideja natjecanja sama po sebi utječe na motiviranost i uključenost, ali u odgojno-obrazovnom sustavu treba imati na umu mogućnost rivalstva među učenicima te negativne učinke.

- Orijentiranost zabavi je princip koji govori o tome da sustav igrifikacije treba biti zabavan za sudionike u igrificiranom okruženju jer zabava utječe na motiviranost $i$ angažman.

Gyldendahl Jensen (2016) navodi drugačije principe, poput ciljeva, razina, sakupljanja itd., koje drugi autori smatraju elementima dizajna igre (Nah i sur., 2014) ili specifičnije mehanikama igre koje se odnose na proces igranja (Werbach i Hunter, citirano u Sailer i sur., 2013). Mehanika igre ustvari se odnosi na pravilo koje se integrira u igru kako bi igrač napredovao kroz igru i ostvario njen cilj. Različiti autori (npr. Fui-Hoon Nah i sur., 2013; Sailer i sur., 2013; Vivas Urías i sur., 2016) navode mnogobrojne mehanike igara, a najčešće korištene opisane su u nastavku:

- Bodovi - mehanika gdje se bodovi dodjeljuju za (ne)ispunjenje zadatka, a primjenom bodovnih skala označava se napredak ili postignuće učenika.

- Razine/Nivoi - mehanika kojom se glavni cilj dekomponira na nekoliko manjih ciljeva, odnosno zadataka. Ispunjavanjem ciljeva svake razine ostvaruje se postignuće. 
- Zadaci/lzazovi - mehanika gdje se glavni cilj razlaže na aktivnosti i zadatke.

- Bedževi/Značke - mehanika kojom se za ispunjenje zadatka ili aktivnosti dodjeljuje „nagrada“ kao vizualni reprezentator uspjeha.

- Ljestvice poretka - mehanike prikazivanja najboljih rezultata, a često su povezane s mehanikom dodjeljivanja bodova za izvršen zadatak ili aktivnost.

- Nagrade - mehanike koje označavaju (ne)materijalne nagrade za ostvarivanje postignuća ili cilja.

- Trake napretka - mehanike koje prate i prikazuju napredak učenika u ostvarivanju ciljeva.

- Priče - mehanike kojima se gradivo i problemi isprepliću s dobrom pričom kako bi se povećala zainteresiranost učenika.

- Avatari - mehanike koje predstavljaju vizualni reprezentator učenika kao što animirani likovi u igrificiranom okruženju.

- Povratna veza - mehanika kojom se učeniku daju informacije o njegovom dosadašnjem performansu i angažmanu. Kao povratna veza mogu se koristiti druge mehanike igrifikacije, kao što su bodovi i bedževi, ali isto tako može se raditi o konkretnim povratnim informacijama konstruktivnog karaktera.

\section{PREGLED PRETHODNIH ISTRAŽIVANJA}

Kako je igrifikacija postala popularna u proteklih nekoliko godina, očekivan je i porast interesa za ovaj koncept među znanstvenicima, ali i stručnom publikom. Capponeto i suradnici (2014) proveli su sistematski pregled znanstvenih radova objavljenih na temu igrifikacije u obrazovanju u periodu od 2000. do početka 2014. godine, te uočili da se nakon 2011. godine naglo povećao broj objavljenih publikacija (206 radova objavljenih 2011. godine nasuprot 1620 radova objavljenih 2013. godine).

Martí-Parreño i suradnici (2016) proveli su sistematski pregled literature na 139 znanstvenih radova objavljenih između 2010. i 2014. godine kako bi identificirali osnovne koncepte i ključne riječi vezane uz upotrebu igara u kontekstu obrazovanja, zatim vodeće časopise koji objavljuju radove i vodeće institucije koje provode istraživanja, te istraživačke metode koje se pritom koriste. Analizom radova autori su utvrdili da je "igrifikacija" značajno manje korišten koncept u odnosu na najistaknutiji koncept "igranje temeljeno na učenju", sugerirajući da je igrifikacija novi pristup u obrazovanju i području istraživanja.

Ortiz i suradnici (2016) fokusirali su se na korištenje igrifikacije u visokom obrazovanju u STEM području. Nakon rigoroznog odabira provedenog tijekom sistematskog pregleda literature, analizom 30 znanstvenih radova utvrdili su da se igrifikacija većinom primjenjuje u polju računalnih znanosti, najčešće kao kombinacija mehanika (bodovi, bedževi i rang liste) te da pozitivno utječe na studentsku aktivnost. 
Poželjnost igrifikacije kao pedagoškog alata u nastavi i njezinu usklađenost s akademskim kurikulumom istraživali su de Byl i Hooper (2013). U njihovom je istraživanju sudjelovao 31 student preddiplomske razine, koji je bio uključen u četiri predmeta tijekom dva semestra, na kojima se nastava provodila prema de Bylinom igrificiranom kurikulumu. Nakon završena oba semestra studenti su anketirani kako bi se utvrdio učinak igrificirane nastave na njihovu aktivnost. Analiza rezultata pokazala je da postoji korelacija studentske aktivnosti s dimenzijom razigranosti (engl. playfulness) i dimenzijom alternativnih pedagogija, tj. da su najaktivniji studenti oni koji se vole igrati i/ili koji preferiraju učenje pomoću alternativnih pedagogija.

Jagušt i suradnici (2017) istraživali su primjenu igrifikacije u nastavi matematike u nižim razredima osnovne škole. U njihovom istraživanju sudjelovalo je 59 učenika drugih i trećih razreda koji su tijekom nastave koristili tablete s matematičkom aplikacijom kojom su ponavljali naučeno gradivo. Aplikaciju su koristili u dva navrata: prvo su na nastavnom satu tijekom 15 minuta samostalno rješavali matematičke zadatke $u$ aplikaciji, a nakon dva tjedna rješavanje istih zadataka u aplikaciji je igrificirano tako da je na tabletu bilo prikazano odbrojavanje vremena, a na platnu je projicirana ljestvica poretka s rezultatima. Analiza logova iz aplikacije utvrdila je da su učenici bili motiviraniji u igrificiranoj okolini jer su u zadanom vremenu dulje zadržavali pažnju i riješili više zadataka. No, korištenje ljestvice poretka za neke je učenike bilo demotivirajuće i kontraproduktivno te nisu postigli dobre rezultate.

Laskowski i Borys (2016) istražili su primjenu koncepta igrifikacije te ozbiljnih igara među 34 nastavnika u visokom obrazovanju, gdje su provjeravali razinu upoznatosti nastavnika s navedenim konceptima te prikupljali informacije o primjeni pojedinih koncepata. Istraživanje je pokazalo da osobe između 30 i 35 godina pokazuju najveći interes za primjenu igrifikacije u svom nastavnom radu. Najveći broj ispitanika kao razlog za korištenje igrifikacije u radu navodi da igrifikacija nastavu čini zanimljivom te povećava učeničku/studentsku motivaciju. Kao razloge za neprimjenu igrifikacije u svom nastavnom radu najveći broj ispitanika navodi da ne znaju što je igrifikacija te da nemaju vremena pripremati igrificirane materijale. Dodatno, ispitanike se pitalo žele li predstaviti igrifikaciju u svom nastavnom radu. Najveći broj odgovora povezan je s povećanjem angažmana učenika/studenta te atraktivnosti nastave. Kao najčešći razlog zašto ne bi koristili igrifikaciju u svom radu ispitanici navode da smatraju kako je igrifikacija trenutni trend i ne žele izrađivati igrificirane materijale.

\section{METODOLOGIJA I UZORAK}

Ciljevi ovog istraživanja bili su: istražiti mišljenja i praksu učitelja o korištenju igrifikacije u nastavi, u kojim se predmetima, od onih obuhvaćenih istraživanjem, najčešće koristi, koji su razlozi njezinog nekorištenja te namjere vezane uz buduće korištenje igrifikacije.

Analizom prikupljenih podataka odgovorilo se na sljedeća istraživačka pitanja:

P1: Jesu li učitelji upoznati s konceptom igrifikacije i koji su razlozi (ne)poznavanja navedenog koncepta?

P2: Na kojoj razini obrazovanja i u kojim predmetima se najčešće primjenjuju mehanike igrifikacije? 
P3: Planiraju li učitelji u bližoj budućnosti češće koristiti mehanike igrifikacije?

Uzorak istraživanja bio je prigodan, a činili su ga učitelji iz osnovnih i srednjih škola u dvije županije, od čega su dvije osnovne i jedna srednja škola bile iz Varaždinske županije, te jedna osnovna i jedna srednja škola iz Brodsko-posavske županije. Navedeni elementi upućuju na ograničenje istraživanja jer u njemu nije korišten reprezentativan uzorak te se radilo o malom uzorku s obzirom na populaciju.

Metoda korištena u istraživanju je metoda ispitivanja usmjerena na prikupljanje podataka o stavovima, mišljenjima i motivima ispitanika vezanim uz ciljeve istraživanja. Tehnika prikupljanja podataka korištena u istraživanju bila je anketni upitnik, koji je distrubuiran ispitanicima u online i papir-olovka obliku u lipnju 2016. godine. U uvodnom dijelu upitnika objašnjen je pojam igrifikacije i pripadna terminologija te anonimnost prikupljenih podataka. Anketni upitnik sastojao se od 17 pitanja, a neka pitanja korištena u anketnom upitniku preuzeta su ili prilagođena iz istraživanja koje su proveli Laskowski i Borys (2016). Pitanjima su se prikupljali podaci o profilu nastavnika te se utvrđivala upoznatost nastavnika s igrifikacijom i njihovo (ne)korištenje igrifikacije u izvedbi nastave. Sljedećim setom pitanja utvrđivali su se razlozi za korištenje ili nekorištenje igrifikacije, kao i namjera budućeg korištenja igrifikacije.

\section{REZULTATI ISTRAŽIVANJA}

\section{1 Profil ispitanika}

Anketnom istraživanju odazvala su se 124 učitelja. Među ispitanicima bilo je 60 (48,39 \%) učitelja koji rade u osnovnoj školi te $64(51,61 \%)$ učitelja koji rade u srednjoj školi. Od ukupnog broja učitelja $24(19,35 \%)$ su iz razredne nastave i $100(80,65 \%)$ iz područja predmetne nastave, od čega 57 (45,97 \%) učitelja predaje jedan predmet, a $43(34,68 \%)$ predaje više predmeta.

Distribucija ispitanika po dobi prikazana je na slici 1, a distribucija ispitanika prema godinama radnog iskustva na slici 2. Može se uočiti da su u uzorku zastupljene sve starosne skupine, a najveći broj ispitanika bio je u dobnoj skupini od 30 do 35 godina.

Slika 1. Godine starosti ispitanika

Slika 2. Godine radnog iskustva ispitanika
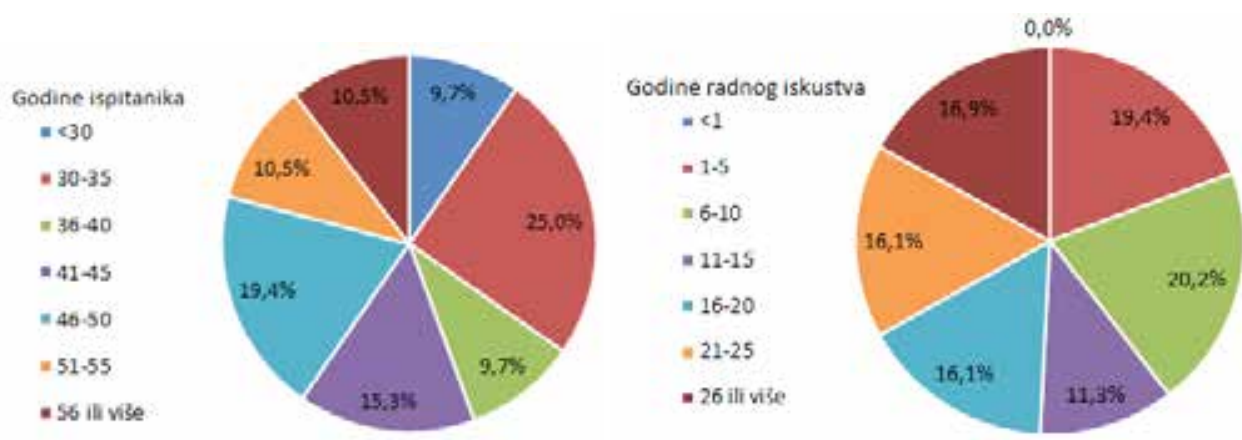

Izvor: autori 


\section{2 Korištenje igrifikacije u nastavi}

Prvim anketnim pitanjem vezanim uz korištenje igrifikacije željelo se utvrditi jesu li ispitanici već odranije upoznati s konceptom igrifikacije. Potvrdno je odgovorilo 39 ispitanika (31.5\%), nije bilo sigurno 17 ispitanika (13.7 \%), dok je više od polovice ispitanika (68 ili $54.8 \%$ ) odgovorilo da nije upoznato s konceptom igrifikacije. Velika zastupljenost negativnih odgovora može biti rezultat nedostatka izobrazbe jer je čak 114 ispitanika (91.9 \%) odgovorilo da nije pohađalo neki oblik izobrazbe na temu igrifikacije. Iz navedenog možemo zaključiti da se većina ispitanika upoznala s konceptom igrifikacije na informalan način.

S obzirom na zastupljenost ispitanika prema različitim dobnim skupinama i raspodjeli njihovih odgovora unutar dobne skupine (vidi sliku 3), uočava se da su s igrifikacijom najmanje bili upoznati ispitanici iz dviju najstarijih. Unutar većine dobnih skupina prevladava nepoznavanje igrifikacije. Jedino je u dobnim skupinama ispod 30 godina te od 36 do 40 godina veći postotak ispitanika izrazio poznavanje koncepta igrifikacije (50 \% u obje skupine) u odnosu na nepoznavanje igrifikacije (41.7\% i $33.3 \%$ ). Budući da se većina ispitanika koji su upoznati s konceptom igrifikacije s njime upoznala na informalan način, možemo zaključiti da je poznavanje koncepta prvenstveno povezano s interesom pojedinog učitelja, što u pravilu odgovara mlađim skupinama ispitanika koje su bile uključene $u$ istraživanje (do 40 godina).

Slika 3. Poznavanje koncepta igrifikacije unutar dobnih skupina

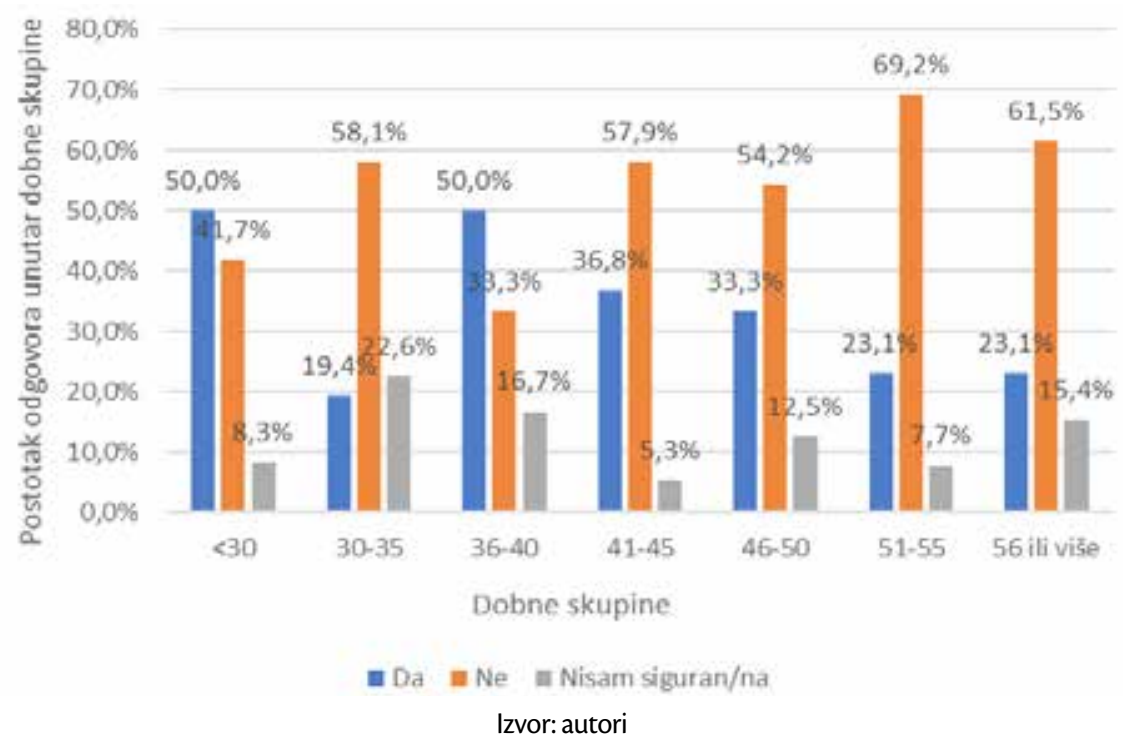

Slično, kao što je vidljivo na slici 4, unutar skupina s najviše radnog iskustva ( 21 do 25 te 26 i više godina), najveći postotak ispitanika nije bio odranije upoznat s konceptom igrifikacije (70 \% i 77,8 \%). Unutar dobne skupine koja ima 11 do 15 godina radnog iskustva (vidi sliku 4) prevladava upoznatost ispitanika s konceptom igrifikacije (50,0 \% odgovora „da“) u odnosu na nepoznavanje igrifikacije (35,7 \% odgovora „ne“ i 14,3 \% odgovora „nisam siguran/na“). Najviše nepoznavanja koncepta igrifikacije iskazali su učitelji s preko 20 godina radnog iskustva. 
Slika 4. Poznavanje koncepta igrifikacije s obzirom na radno iskustvo u nastavi

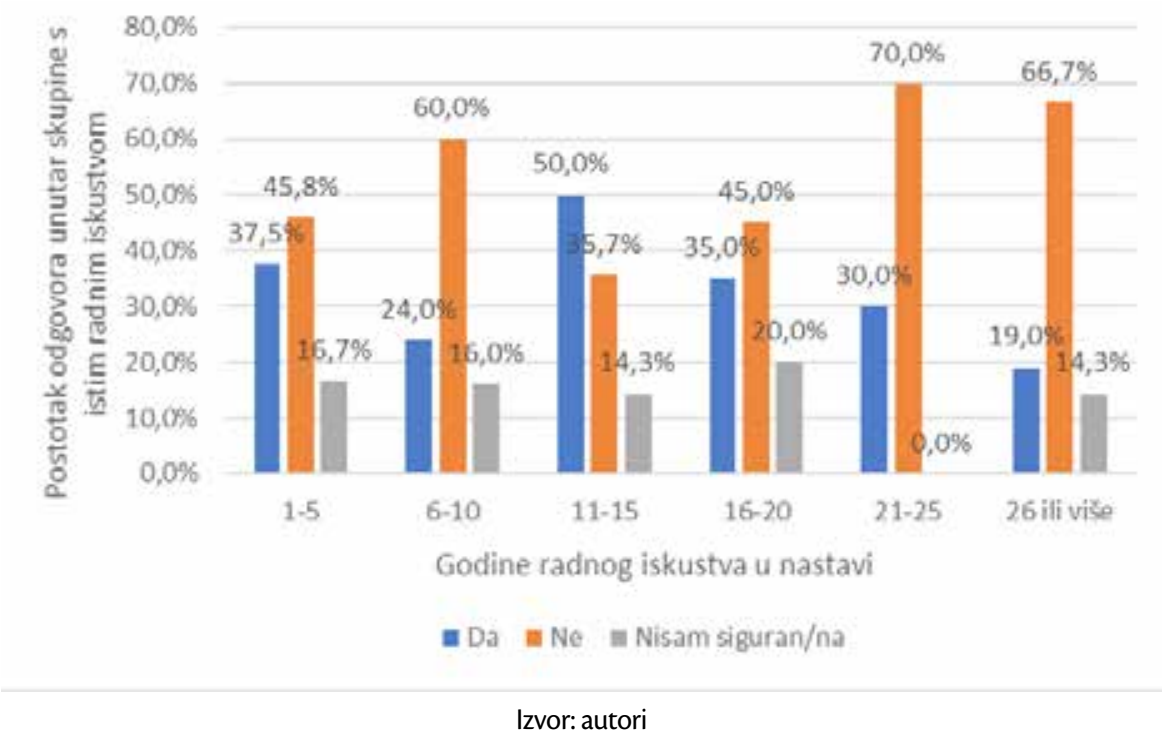

Na pitanje o primjeni igrifikacije u nastavnom radu 48 ispitanika (39.0 \%) odgovorilo je potvrdno, 23 ispitanika (18.0 \%) nije bilo sigurno primjenjuje li je u svom radu, a dok je negativno odgovorilo 39 ispitanika (43.0 \%). Ovdje uočavamo nekonzistentnost u odnosu na odgovore o poznavanju igrifikacije jer je veći broj ispitanika (za $7.5 \%$ ) odgovorio da primjenjuje igrifikaciju.

Analizom je utvrđeno da se igrifikacija nešto više primjenjuje u srednjim školama, gdje je primjenjuje 26 ispitanika (20,97\%) koji su na pitanje o primjeni igrifikacije odgovorili potvrdno, te 22 ispitanika $(17,74 \%)$ u osnovnim školama. Ispitanika koji su na pitanje odgovorili s "ne" ima $30(24,19 \%)$ u osnovnim školama, a u srednjima njih 23 (18,55 \%). Što se tiče radnog iskustva, slično kao i kod poznavanja koncepta igrifikacije, najviše ispitanika koji koriste igrifikaciju u nastavi ima između 11 i 15 godina nastavnog iskustva (50 \%), a slijede ih ispitanici s 1 - 5 godina radnog iskustva ( $45.8 \%$ ).

U nastavku se ispitanike pitalo koje mehanike igrifikacije primjenjuju u svom nastavnom radu. Svaka mehanika bila je opisana, a ispitanici su na skali od 1 (ne primjenjujem) do 4 (stalno primjenjujem) označili koliko često primjenjuju mehaniku. Na pitanje je odgovorio 71 ispitanik, tj. samo oni koji igrifikaciju primjenjuju. Mehanike koje ispitanici često ili stalno primjenjuju su priče (47.9 \%), bodovi (35.2 \%) i zadaci/izazovi (33.8\%), dok nimalo ili ponekad primjenjuju avatare i trake napretka $(97.3 \%)$ te bedževe/značke ( $91.5 \%$ ). Slika 5 daje detaljan uvid u odgovore ispitanika o učestalosti primjene pojedine mehanike igrifikacije. 
Slika 5. Učestalost primjene mehanika igrifikacije

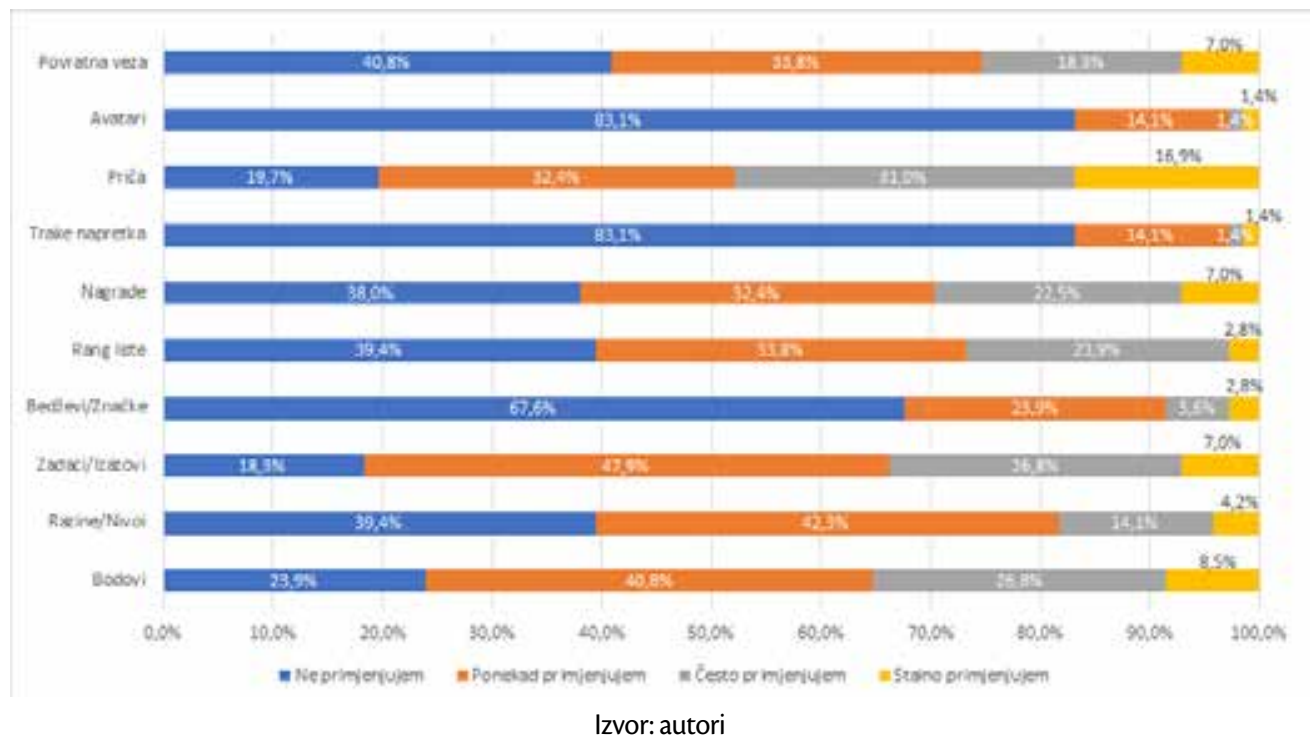

Predmeti u kojima ispitanici najčešće koriste igrifikaciju su Matematika (13 ispitanika ili 10,48 \%), Hrvatski jezik (10 ispitanika ili 8,06 \%) te strani jezici (11 ispitanika ili 8,87\%). Od ostalih predmeta u kojima ispitanici primjenjuju igrifikaciju navedeni su Priroda i društvo, Geografija, Informatika, Kemija, Fizika, Vjeronauk te stručni predmeti iz područja elektrotehnike, informatike i cestovnog prometa. Ispitanici su u otvorenom tipu pitanja naveli računalne aplikacije koje koriste za igrifikaciju. Analizom je utvrđeno da se na satu Hrvatskoga jezika koriste igrificirane aplikacije za provjeru znanja, poput HotPotatoe, Match the Memory, Quiz Revolutions, Purpose Games i Kahoot, a potonji se koristi i na satovima stranih jezika. U Matematici se koriste Kahoot, Geogebra i Stellarium.

Više od polovice ispitanika koji primjenjuju igrifikaciju složilo se s tvrdnjama o pozitivnim učincima igrifikacije na učenike (vidi sliku 6). Najviše ispitanika (48 ili $64.8 \%$ ) slaže se ili se u potpunosti slaže s tvrdnjom da su učenici više motivirani za nastavu, zatim da su učenici više zainteresirani za nastavni predmet u cjelini (47 iili 66.2 \%) i da se žele uključiti u dodatne aktivnosti koje su vezane uz igrifikaciju (46 ili $64.8 \%$ ). Najmanje ispitanika složilo se ili se u potpunosti složilo da učenici postižu bolje rezultate (37 ispitanika ili $52.7 \%$ ), a značajan dio ispitanika je neutralan po tom pitanju (29 ili $40.8 \%$ ). 
Slika 6. Učestalost slaganja ispitanika s tvrdnjama o učincima igrifikacije

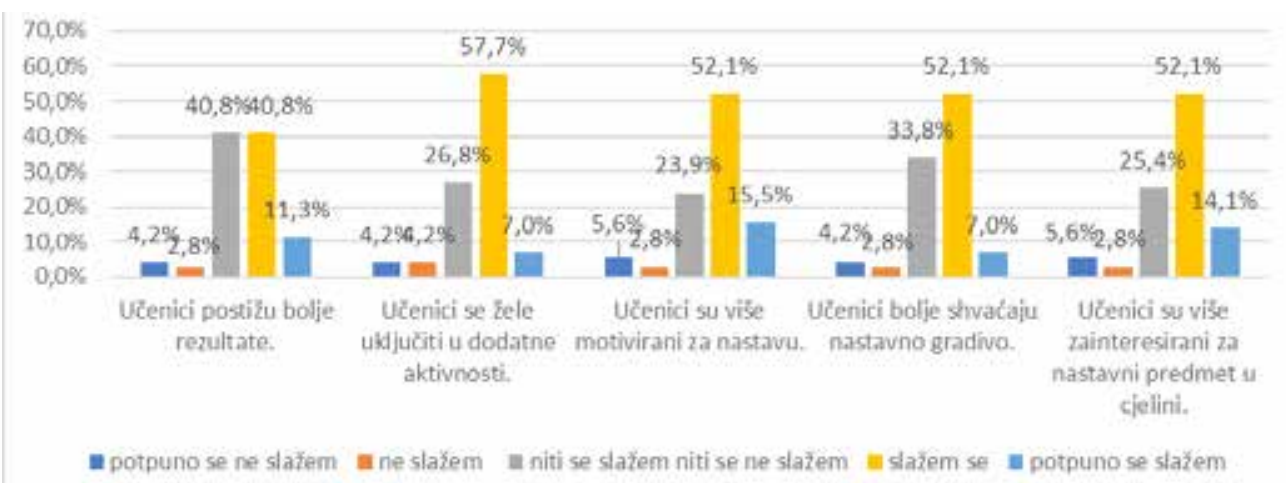

Izvor: autori

\subsection{Razlozi (ne)korištenja igrifikacije}

$\mathrm{Na}$ pitanje o razlozima zbog kojih primjenjuju igrifikaciju u nastavnom radu izjasnilo se 124 ispitanika koji su mogli dati veći broj odgovora (vidi sliku 7). Kao glavne razloge za korištenje igrifikacije ispitanici su naveli povećanje motivacije (52 ispitanika ili $41.9 \%$ ) i atraktivniji nastavni sat (42 ili $33.9 \%$ ). Dio ispitanika okrenut je i usavršavanju nastavničkih vještina pa je oko četvrtine njih kao razlog navelo eksperimentiranje s tehnikama poučavanja (29 ili $23.4 \%$ ) ili želju za inovativnošću (21 ili 16.9\%). Samo četiri ispitanika (3.2 \%) navela su da igrifikaciju koriste kako bi provjerili njene učinke na usvojenost znanja.

Slika 7. Razlozi korištenja igrifikacije u nastavnom radu

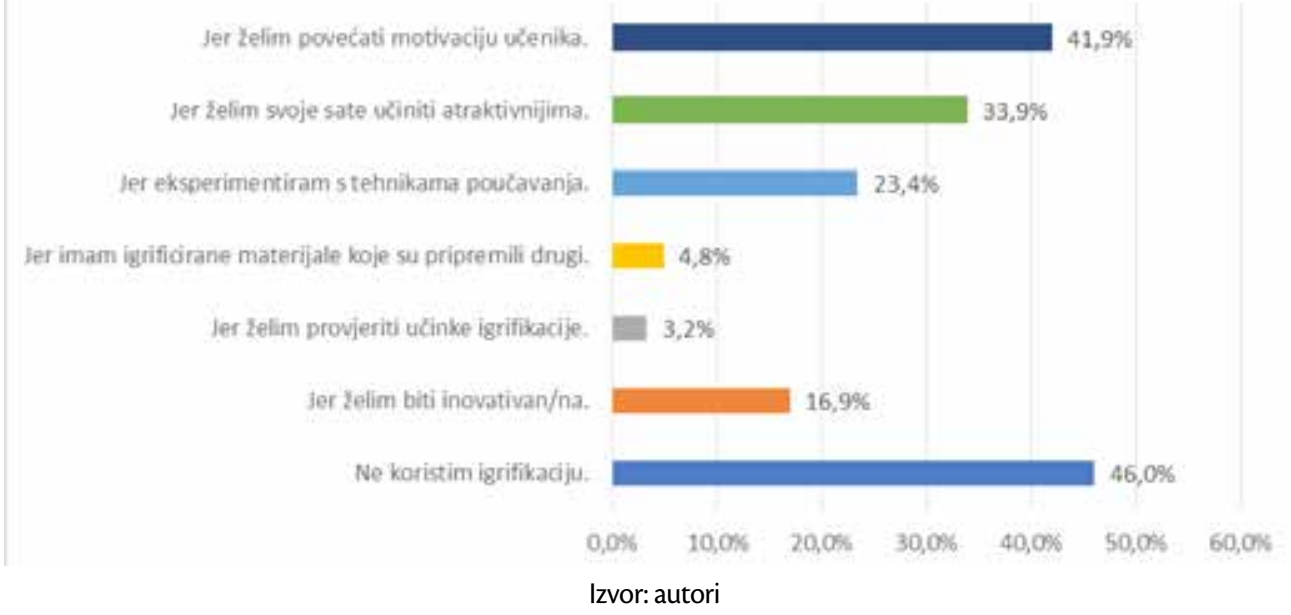

Ispitanike se također pitalo koji su razlozi zbog kojih ne koriste igrifikaciju u nastavnom radu ili je koriste u manjoj mjeri od željene (vidi sliku 8). Odgovore su dala 123 ispitanika. Kao vodeće razloge za nekorištenje igrifikacije ispitanici su naveli nedostatak vremena za pripremu igrificiranih 
nastavnih sadržaja (56 ili 43.9 \%) i nepoznavanje koncepta igrifikacije (36 ili $29.3 \%$ ). Manji dio ispitanika ne zna kako igrificirati nastavni sat (20 ili $16.3 \%$ ) ili kako bi učenici reagirali na takav način rada (6 ili $4.9 \%$ ). Jedan ispitanik smatra da igrifikacija nema pozitivne učinke na kvalitetu nastave. Ispitanici su naveli i neke svoje razloge neprimjene igrifikacije, poput nedostatka potrebne opreme, nedostatka izobrazbe iz igrifikacije, nemogućnost primjene igrifikacije zbog karakteristika nastavnog gradiva ili strukture razreda, a navedena je i nemotiviranost zbog lošeg položaja učitelja u društvu.

Slika 8. Razlozi nekorištenja igrifikacije ili njena korištenja u manjoj mjeri

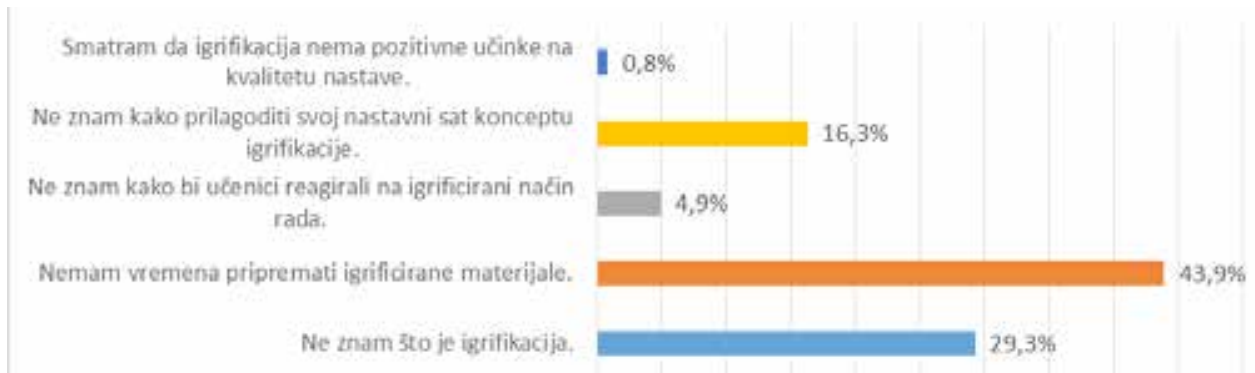

$0,0 \% 5,0 \% 10,0 \% 15,0 \% 20,0 \% 25,0 \% 330,0 \% 35,0 \% 40,0 \% 45,0 \% 50,0 \%$

Izvor: autori

\subsection{Namjera budućeg korištenja igrifikacije}

U posljednjem dijelu anketnog upitnika ispitanike se pitalo o namjeri korištenja igrifikacije odnosno njene češće primjene ili neprimjene u budućnosti. Kao i u prethodnim pitanjima ispitanici su mogli označiti više odgovora, a na pitanje o razlogima zbog kojih bi (više) primjenjivali igrifikaciju u svom radu odgovorila su 122 ispitanika (vidi sliku 9). Kao glavne razloge zbog kojih bi (više) primjenjivali igrifikaciju, ispitanici su naveli povećanje pažnje i angažmana učenika (58 ili $47.4 \%$ ) te povećanje kvalitete nastavnog predmeta (58 ili $46.8 \%$ ). 
Slika 9. Razlozi za (češću) primjenu igrifikacije

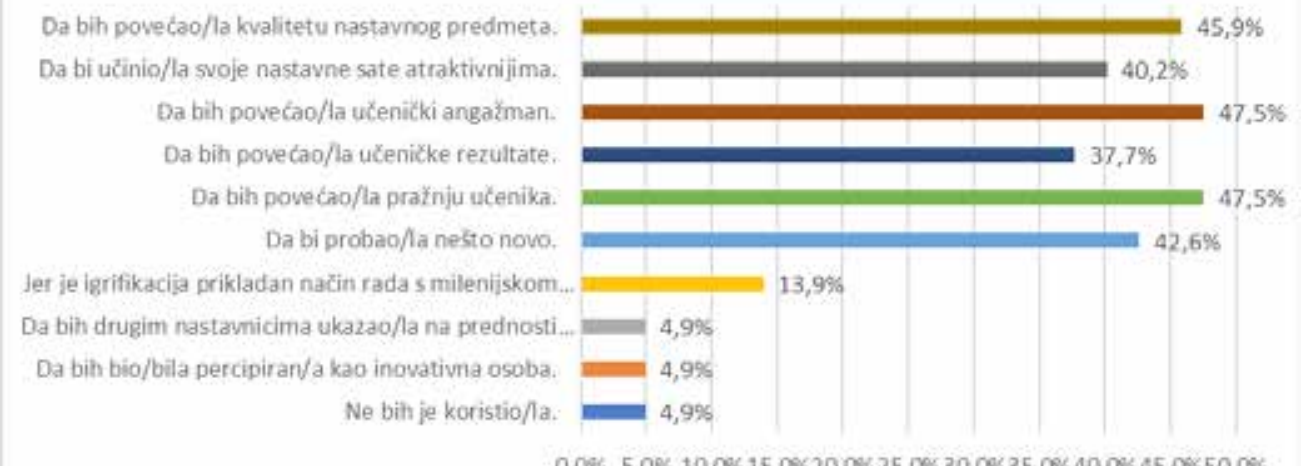

$0,0 \% 5,0 \% 10,0 \% 15,0 \% 20,0 \% 25,0 \% 30,0 \% 35,0 \% 40,0 \% 45,0 \% 50,0 \%$

Izvor: autori

Rezultati pokazuju da su učitelji okrenuti novim nastavnim metodama (42.6 \%) i žele svoj sat učiniti atraktivnijima (40.2 \%). Nešto manji broj ispitanika ima u fokusu rezultate učenika ( $37.7 \%)$. No, bez obzira na sve prednosti, šest ispitanika (4.9\%) dodalo je svoj odgovor u kojem su naveli da i dalje ne namjeravaju koristiti igrifikaciju.

Kao najveće razloge zbog kojih ne bi primjenjivali igrifikaciju ispitanici navode razloge formalne prirode (29 ili $23.4 \%$ ) i tešku integraciju igrifikacije u nastavu (28 ili $22.6 \%$ ). Manjem dijelu ispitanika ne sviđa se koncept igrifikacije i smatraju je trenutnim trendom. Uz ostale odgovore koji su prikazani na slici 10, ispitanici su kao razloge neprimjene igrifikacije dodali nedostatak vremena, neprimjenjivost igrifikacije u nekim situacijama/razredima, te nedostatak motivacije i edukacije.

Slika 10. Razlozi za neprimjenu igrifikacije

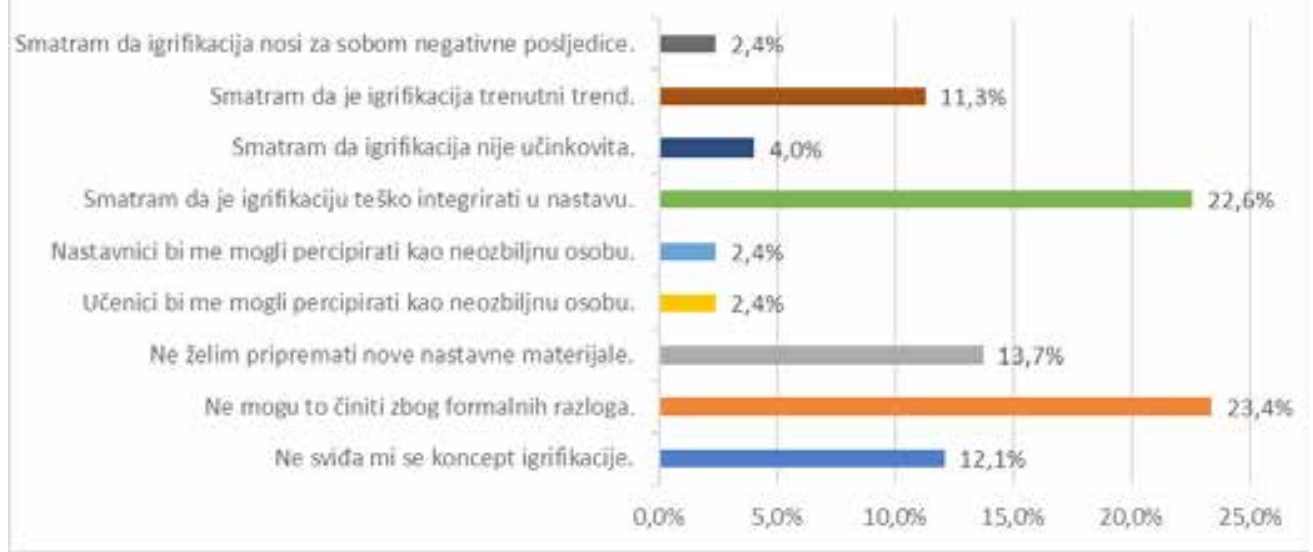

Izvor: autori 


\section{DISKUSIJA}

Najviše rasprave u kontekstu igrifikacije vodi se oko nemogućnosti povezivanja igre, zabave i procesa učenja. Tulloch (2014) u svom pedagoškom osvrtu navodi kako bi proces učenja trebao biti zabavan te da igrifikacija svojim karakteristikama pomaže u tome. Također navodi kako igrifikacija nije nova vrsta pedagogije, već nastavak postojeće. Upravo to ide u prilog činjenici da se igrifikacija može integrirati u svaki nastavni predmet. Prema rezultatima ovog istraživanja igrifikacija se najviše primjenjuje u izvođenju općih predmeta s najviše sati nastave, pa se može zaključiti kako se današnjim generacijama želi pružiti suvremenija nastava i zabavniji proces učenja. lako bi prema Tullochu (2014) igrifikacija trebala biti nastavak postojeće pedagogije, neki ispitanici kao razlog nekorištenja navode da smatraju igrifikaciju trenutnim trendom, što je utvrđeno i u istraživanju Laskowskog i Borys (2016).

U kontekstu igrifikacije kao nastavka postojeće pedagogije mogu se iskoristiti rezultati dobnih skupina koje ju žele ili ne žele primjenjivati. Prema rezultatima istraživanja starije generacije učitelja manje su sklone primjeni koncepta igrifikacije. Razlog tome može biti u stavu da njezin koncept smatraju neprilagođenim tradicionalnoj nastavi. Kada navedene rezultate povežemo s rezultatima poznavanja koncepta igrifikacije unutar dobnih skupina prikazanih u slici 3, možemo spekulirati da učitelji koji pripadaju starijoj dobnoj skupini s više godina radnog iskustva u pravilu manje prate suvremene pedagoške pristupe i trendove. Bez obzira na razlog nepoznavanja koncepta igrifikacije, koji bi trebalo dodatno istražiti, velik izazov koji se postavlja pred sustav je informiranje učitelja o novim spoznajama u području pedagogije. Pozitivno je da je dio učitelja upoznat s konceptom igrifikacije, a dio njih ga i aktivno primjenjuje u nastavi. Samo manji broj učitelja s igrifikacijom se upoznao kroz neformalno obrazovanje (stručne skupove, radionice i sl.), što otvara prostor za proaktivno djelovanje.

Usporedimo li rezultate ovog istraživanja sa sličnim istraživanjem provedenim u Poljskoj među 34 akademska nastavnika (Laskowski, Borys, 2016), možemo uočiti sličnosti u razlozima korištenja i nekorištenja igrifikacije. Obje skupine nastavnika igrifikacijom ponajprije žele povećati motivaciju učenika te svoje nastavne sate učiniti atraktivnijima, a to rade jer žele eksperimentirati s tehnikama poučavanja. Dodatno, kod obje skupine kao glavni razlozi nekorištenja igrifikacije identificirani su nedostatak vremena za pripremu igrificiranih materijala, nepoznavanje koncepta igrifikacije i nepoznavanje tehnika integriranja igrifikacije u nastavni sat. Nasuprot tome, dok najviše hrvatskih ispitanika nema namjeru koristiti igrifikaciju zbog ograničenja formalnog sustava obrazovanja, kod poljskih ispitanika taj razlog uopće nije identificiran.

Franković (2016) smatra da se interes za učenjem može povećati primjenom igara ili njezinih elemenata jer pružaju zanimljivo okruženje za stjecanje znanja. $U$ ovom istraživanju utvrđeno je da mnogi učitelji traže načine i primjenjuju različite računalne igre i aplikacije kako bi učenicima učinili nastavu zanimljivijom. Neke od aplikacija i igara moguće je primjenjivati u svim nastavnim predmetima, a najčešće navođene u ovom istraživanju su Kahoot i Purpose Game. Suprotno tome, neke od aplikacija su specijalizirane za pojedini predmet, pa se, primjerice, Geogebra dominantno koristi u nastavi Matematike. Vidljivo iz slike 10 je da učitelji koji koriste igrifikaciju u sklopu svoje nastave igrifikaciju najčešće koriste za povećanje aktivnosti i motivacije učenika. Navedeni rezultati 
u skladu su s konceptom igrifikacije te se može zaključiti da dio učitelja kvalitetno promišlja i koristi koncept igrifikacije u nastavnoj praksi.

\section{ZAKLJUČAK}

Ideja primjene mehanika igara tijekom nastavnog procesa, uz korištenje informacijskokomunikacijskih tehnologija, prisutna je dulji niz godina, no tek su se u posljednjih nekoliko godina u svijetu intenzivirala istraživanja o korištenju i učinkovitosti igrifikacije u obrazovnom sustavu. Igrifikacijom se želi utjecati na aktivnosti i motivaciju učenika kako bi učenje za učenika predstavljalo ugodan proces i rezultiralo usvajanjem znanja, a što je vidljivo i u rezultatima provedenog istraživanja.

U sklopu provedenog istraživanja odgovoreno je na tri postavljena istraživačka pitanja. $U$ analizi rezultata vezanih uz prvo istraživačko pitanje (P1) uočeno je da većina učitelja nije upoznata s konceptom igrifikacije. Glavni razlog navedenog stanja je nedostatak izobrazbe koji bi obuhvaćao i upoznavanje s konceptom igrifikacije. U sklopu drugog istraživačkog pitanja (P2) utvrđeno je da se mehanike igrifikacije nešto više koriste na srednjoškolskoj razini, a predmeti u kojima su mehanike igrifikacije najčešće primjenjivane su Matematika, Hrvatski jezik i strani jezici. Odgovorom na treće istraživačko pitanje (P3) zaključeno je da je većina učitelja zainteresirana za primjenu mehanika igrifikacije primarno radi povećanja pažnje i aktivnosti učenika te unapređenja kvalitete nastavnog procesa.

Najveći broj istraživanja o igrifikaciji proveden je u sustavu visokog obrazovanja. Istraživanjem predstavljenim u ovom radu želi se dati doprinos u uočavanju stanja primjene koncepta igrifikacije u Republici Hrvatskoj na razini primarnog i sekundarnog obrazovanja. Rezultati istraživanja provedenog na prigodnom uzorku od 124 ispitanika iz tri osnovne i dviju srednjih škola pokazali su da igrifikacija još nije u velikoj mjeri zaživjela u hrvatskom obrazovnom sustavu jer tek oko polovice ispitanika koristi igrifikaciju u svom nastavnom radu. No, koncept igrifikacije primjenjuje se i u osnovnim i u srednjim školama, ali ju ne primjenjuju, niti su s njome upoznati svi učitelji. Starije generacije pokazuju nižu sklonost korištenju igrifikacije. Igrifikaciju nije obavezno koristiti te svaki učitelj odlučuje želi li je integrirati u svoj rad i na koji će način to učiniti. Preduvjet takve odluke je da učitelji budu upoznati s konceptom igrifikacije, a odgojno-obrazovni sustav trebao bi dinamičnije podržati integraciju tehnologija i vezanih koncepata primjene u nastavni proces.

Osnovno ograničenje ovog istraživanja leži u nereprezentativnosti uzorka te se zaključci istraživanja ne mogu generalizirati na sve nastavnike $u$ hrvatskim osnovnim i srednjim školama. $U$ budućim istraživanjima bilo bi poželjno rezultate provedenog istraživanja usporediti s reprezentativnijim uzorkom te dodatno istražiti kako učitelji primjenjuju mehanike igrifikacije u nastavi jer je uočena nekonzistentnost u odgovorima vezanim uz primjenu igrifikacije u nastavnom radu. Dodatno, u budućim istraživanjima bilo bi zanimljivo pristupiti tematici iz perspektive učenika te provesti usporedbu rezultata odgovora učenika i učitelja kako bi se utvrdili elementi podudarnosti i neslaganja. Kasnija istraživanja mogla bi se usmjeriti prema utvrđivanju razloga podudarnosti i različito percipiranih elemenata između učenika i učitelja. 


\section{LITERATURA}

Caponetto, I., Earp, J., Ott, M. (2014) „Gamification and education: A literature review”. In: European Conference on Games Based Learning. Academic Conferences International Limited, p. 50.

Deterding, S., Dixon, D., Khaled, R., Nacke, L. (2011) “From game design elements to gamefulness: defining gamification”. In: Proceedings of the 15th International Academic MindTrek Conference: Envisioning Future Media Environments. ACM, p. 9-15.

de Byl, P., Hooper, J. (2013) “Key Atributes of Engagement in a Gemified Learning Enviroment". In: Electric Dreams 30th ascilite Conference, p. 221-230.

Edmonds, S. (2011) "Gamification in learning". Training and Development in Australia, Vol. 38, No. 6, p. 20-22.

Franković, I. (2016) “Učenje temeljeno na didaktičkim računalnim igrama”. Rijeka: Sveučilište u Rijeci, Odjel za informatiku.

Fui-Hoon Nah, F., Rallapalli, S., Rajasekhar Telaprolu, V., Rallapalli Venkata, P. (2013) “Gamification od Education Using Computer Games". In: S. Yamamoto (Ed.): HIMI/HCII 2013, Part III, LNCS 8018, Springer-Verlag Berlin Heidelberg, p. 99-107

Gyldendahl Jensen, C. (2016) “GAMIFICATION OF INNOVATION PROCESSES BY BRINGIGN „WORLD OF WARCRAFT“ TO REAL WORLD". In: Proceedings of EDULEARN16 Conference, p. 59-68.

Isayama, D., Ishiyama, M., Relator, R., Yamazaki, K. (2016) "Computer Science Education for Primary and Lower Secondary School Students: Teaching the Concept of Automata". ACM Trans. Comput. Educ. 17, 1-28. https://doi. org/10.1145/2940331

Jagušt, T., Botički, I., Mornar, V., So, H.-J. (2017) “Gamified Digital Math Lessons for Lower Primary School Students”, In: 6th International Conference on Learning Technologies and Learning Environments (LTLE2017)

Jackson, M. (2016) "Gamification in Education: A Literature Review". Preuzeto s http://www.westpoint.edu/cfe/ Literature/MJackson_16.pdf (13. 5. 2017).

Kiryakova, G., Angelova, N., Yordanova, L. (2014) "Gemification in education". In: 9th International Balkan Education and Science Conference, Edirne, Turkey

Laskowski, M., Borys, M. (2016) “THE STUDENT, THE PROFESSOR AND THE PLAYER: USAGE FOR GAMIFICATION AND SERIOUS GAMES IN ACADEMIC EDUCATION - A SUVERY". In: Proceedings of EDULEARN16 Conference, p. 2933-2941.

Martí-Parreño, J., Méndez-Ibáñez, E., Alonso-Arroyo, A. (2016) “The use of gamification in education: a bibliometric and text mining analiysis". Journal of Computer Assisted Learning 32, p. 663-676.

McGrath, N., Bayerlein, L. (2013) “Engaging online students through the gamification of learning materials: The present and the future". In: Electric Dreams 30th ascilite Conference, p. 573-577.

Medica Ružić, l., Dumančić, M. (2015) “Gamification in education”. Informatologija Vol. 48 No.3-4., p. 198-204.

Ortiz, M., Chiluiza, K., Valcke, M. (2016) "GAMIFICATION IN HIGHER EDUCATION AND STEM: A SYSTEMATIC REVIEW OF LITERATURE". In: Proceedings of EDULEARN16 Conference, p. 6548-6558.

Pivac, M. (2016) „Igra i učenje: Potencijali učenja kroz igru“. In: Edupoint, http://edupoint.carnet.hr/casopis/49/clanci/1. html (6.5. 2017.)

Sailer M., Hense, J., Heinz, M., Klevers, M. (2013) "Psychological Perspectives on Motivation through Gamification". Interaction Design and Architecture(s) Journal - IXD\&A, N.19, p. 28-37.

Sandusky, S. (2017) "Gemification in Education". In: The University of Arizona UA Campus Repository, http://dspace. uni-sz.bg/handle/123456789/12 (6.5. 2017.)

Vivas Urías, M.D., Cruz Chust, A., Liébana Carrasco, O. (2016) “HOW TO GAMIFY AN ONLINE TECHNICAL SUBJECT IN HIGHER EDUCATION". In: Proceedings of EDULEARN16 Conference, p. 7071-7081.

Tulloch, R. (2014) “Reconceptualising gamification: play and pedagogy”. Digital Culture \& Education 6:4, p. 317-333. 


\title{
TEACHERS' USAGE AND ATTITUDES TOWARDS GAMIFICATION IN PRIMARY AND SECONDARY SCHOOLS
}

\begin{abstract}
During the past several years a concept of gamification has drawn much attention among researchers and teachers due to its benefits related to motivation and engagement of learners. While this educational approach, that incorporates game mechanics into the teacher's class, is mainly explored in higher education settings, the researches about gamification at lower levels of education are sparse. This paper provides the findings of the survey conducted among 124 teachers employed at three primary and two secondary schools in Croatia about the usage of gamification as well as attitudes towards gamification in general. The research results give insights into the profiles of the teachers who use or do not use gamification during their classes, and identify gamification mechanics and applications they employ. Teachers' opinions about the gamification and the reasons for (not) introducing it into the class are also presented. According to the research results, it is possible to conclude that less than half of the respondents were familiar with the concept of gamification and that they applied it in their work. The research results show that most of the teachers got acknowledged with the concept of gamification on a personal initiative. Points, quests and storylines are the mechanics of gamification that the respondents most often applied in their work. Courses in which respondents the most frequently applied gamification were the mathematics, Croatian language and foreign languages. Also, the respondents in high percentage agreed with the effects and impacts of gamification on motivation and engagement of students, which represent the benefits of gamification. The lack of time and formal reasons were indicated as the reasons for non-usage of gamification, while motivation and engagement were set out as reasons for the usage of gamification.
\end{abstract}

Key words: gamification, teachers, primary school, secondary school, survey

1 PhD, Assistant Professor, Faculty of Orgnaization and Informatics, University of Zagreb,Pavlinska 2, 42000 Varaždin, Croatia. E-mail: dijana.plantak@foi.hr

2 BA in Informatics, E-mail: majaskara1990@gmail.com

3 PhD, Assistant Professor, Faculty of Orgnaization and Informatics, University of Zagreb Pavlinska 2, 42000 Varaždin, Croatia. E-mail: goran.hajdin@foi.hr 